\title{
Literasi Berbahasa Indonesia Usia Prasekolah: Ancangan Metode Dia Tampan dalam Membaca Permulaan
}

\author{
Khirjan Nahdi ${ }^{\varpi_{1}}$, Dukha Yunitasari ${ }^{2}$ \\ Pendidikan Bahasa dan Sastra Indonesia, Universitas Hamzanwadi ${ }^{1}$ \\ Pendidikan Guru Sekolah Dasar, Universitas Hamzanwadi² \\ DOI: $10.31004 /$ obsesi.v4i1.372
}

\begin{abstract}
Abstrak
Perkembangan literasi berbahasa membaca permulaan anak usia dini merupakan salah satu aspek yang harus dicapai oleh anak dalam perkembangannya. Tujuan dari penelitian ini adalah untuk melihat perkembangan literasi berbahasa membaca permulaan anak usia 5-6 tahun dengan menggunakan metode dia tampan. Penelitian ini menggunakan jenis penelitian kualitatif dengan menggunakan analisis kualitatif deskriptif. Teknik pengumpulan data dengan menggunakan observasi, wawancara dan dokumentasi dengan instrument pengumpulan datanya adalah lembar pedoman wawancara, dan lembar observasi. Teknik analisis data yang digunakan menggunakan analisis deskriptif miles \& Hubberman. hasil yang diperoleh dari penerapan metode dia tampan untuk mengembangkan kemampuan literasi Bahasa membaca permulaan anak yang paling dominan adalah masuk ke dalam kriteria" berkembang sesuai harapan", sedangkan yang paling sedikit kemampuan membaca permulaan anak usia 5-6 tahun adalah kriteria "mulai berkembang". Faktor pendukung yang mempengaruhi peningkatan ini, dikarenakan proses pembelajaran yang aktif dengan menggunakan strategi dia tampan yang membuat anak serta anak-anak menemukan hal yang baru dan lebih terlihat kesempatan berkomunikasi sesama temannya.
\end{abstract}

Kata Kunci: literasi berbahasa; membaca permulaan; dia tampan; 5-6 tahun.

\section{Abstract}

The development of literacy while reading reading early childhood is one aspect that must be agreed by the child in its development. The purpose of this study is to look at the development of early literacy reading among children aged 5-6 years using the method he is handsome. This research uses qualitative research by using descriptive qualitative analysis. Data collection techniques using observation, interviews and documentation with data collection instruments are interview guide sheets, and observation sheets. Data analysis technique used is the descriptive analysis of miles \& Hubberman. The results obtained from the application of his handsome method to develop English literacy skills in reading the beginning of the child are the most dominant entry into the criteria "developing as expected", while the least ability to read the beginning of children aged 5-6 years is a hint "start developing". Supporting factors that influence this increase, because the active learning process by using the strategy he is handsome that makes children find something new and more visible.

Keywords: language literacy; beginning reading; dia tampan; 5-6 years old.

Copyright (c) 2019 Khirjan Nahdi, Dukha Yunitasari

$\triangle$ Corresponding author:

Email Address : khirjan.nw@gmail.com (Jln TGKH Zainuddin Abdul Madjid No 125 Pancor Lombok

Timur, Nusa Tenggara Barat)

Received 13 December 2019, Accepted 20 December 2019, Published 21 December 2019 


\section{PENDAHULUAN}

Anak Usia Dini adalah seorang anak yang sedang mengalami porses perkembangan yang sangat pesat untuk kehidupan selanjutnya. (Yuliani Nurani, 2012) menjelaskan anak usia dini memiliki rentang usia 0-6 tahun. Usia ini memiliki ciri khas dalam perubahan tingkah laku. Anak usia dini merupakan kelompok usia anak yang berada dalam proses pertumbuhan dan perkembangan yang bias disebut dengan masa golden age (Suyadi, 2017). Proses perkembangan keemasan anak dimulai sejak bayi sehingga Sifat dari perkembangan anak usia dini dapat dikatakan unik. Makna dari unik adalah pola pertumbuhan dan perkembangan anak usia dini mengacu kepada factor usia dan tahap perkembangannya (Palupi, 2015). Menurut teori kognitif Santrock, anak usia dini masuk kedalam tahap praoperasional. Tahap praoperasional itu sendiri adalah tahap dimana seorang anak mengkonstruksi yang didapatkan dari yang dilihat dengan pemikirannya sendiri (Inten, 2017). Pada masa usia dini terdapat 6 aspek perkembangan yang harus dicapai oleh anak. Berdasarkan UU no 146 tahun 2014 tentang standar pembelajaran anak usia dini 6 aspek perkembangan tersebut adalah perkembangan Fisik dan Motorik, perkembangan kognitif, perkembangan seni, perkembangan social-emosional, perkembangan nilai agama dan moral serta perkembangan literasi atau bahasa ((Nur Azizah \& Ali, 2015).

Salah satu aspek perkembangan yang menjadi fokus penting dalam pembelajaran pada anak usia dini adalah perkembangan literasi anak usia dini Proses penekanan membaca, menulis dan berhitung (Calistung) membuat perkembangan literasi anak usia dini menjadi perhatian penting dalam proses Pendidikan terutama dalam Pendidikan anak usia dini. Akan tetapi, menurut world's most literate nations ranked tahun 2016, budaya litearsi masyarakat di Indonesia sangat rendah (Sumaryanti, 2018). Rendahnya budaya literasi sangat dipengaruhi oleh berbagai factor yang diantaranya adalah memiliki waktu luang untu membaca, perkembangan teknologi dan contoh dari orang tua. oleh karena itulah literasi anak sangat penting dalam perkembangan anak.

Literasi itu sendiri secara etimologis berasal dari Bahasa latin yaitu literatus yang artinya ditandai dengan huruf, melek huruf atau berpendidikan, Sedangkan secara istilah literasi adalah sebuah kemampuan membaca dan menulis (Basyiroh, 2017). (Olufunke, 2013) mendefinisikan literasi pada anak usia dini adalah kemampuan dalam mengidentifikasi, memahami, menginterpretasi, membuat, mengkomunikasikan dan menghitung berbagai isi tulisan yang tergabung dalam berbagai variasi isi yang menyiapakn anak untuk belajar dan mengembangkan pengetahuan dan mampu beradaptasi dengan lingkungannya. (Inten, 2017; Nuraeni, 2016) menjelaskan literasi anak adalah kemampuan membaca dan menulis sebagai upaya untuk meningkatkan rasa saling menghargai, mengkritisi, dan menggunakan informasi yang dimilikinya untuk kebaikan. Literasi itu sendiri dapat dikatakan sebagai kemelekan huruf, mengenal tulisan, serta dapat membaca tulisan. Hurlock dalam (Chairilsyah, 2019) menjelaskan kemampuan literasi pada anak mempengaruhi perkembangan social-emosional, emosi, perkembangan kognitif dan yang paling utama adalah perkembangan bahasanya. Jika anak mampu berkomunikasi dengan lingkungan sekitar maka akan tumbuh kepercayaan anak dan dapat melakukan interaksi dan sosialisasi dengan lingkungan sekitarnya. Kemampuan literasi baik secara lisan maupun tulisan seperti membaca dan menulis merupakan kemampuan dasar yang harus dimiliki oleh setiap anak.

Salah satu kemampuan literasi berbahasa yang ada salah satunya adalah membaca permulaan. (Habibi, 2018) menjelaskan membaca permulaan sebagai sesuatu kesatuan kegiatan yang mencakup berbagai kegiatan seperti mengenal huruf dan kata-kata, menghubungkan kata-kata dan bunyi, serta menarik kesimpulan mengenai maksuda dari bacaan yang ada. Memca permulaan atau membaca awal lebih menekankan pada pengenalan dan pengucapan lambing-lambang bunyi yang terdiri dari huruf, kata maupun kalimat dalam bentuk sederhana, membaca juga merupakan aktivitas auditif dan visual untuk memperoleh makna dan symbol berupa huruf atau akta-kata yang meliputi proses membaca teknis maupun proses memahami (Astuti, 2016; Awal \& Mutiara, 2019). 
Proses membaca permulaan menjadi factor penting pada masa usia dini terutama dalam penerapan pembelajaran di PAUD. Hal ini dikarenakan penekanan keberhasilan dalam perkembangan membaca anak menjadikan aspek perkembangan anak terutama perkembangan literasi Bahasa menjadi factor penting yang harus selalu menjadi aspek utama dalam proses pembelajaran di PAUD. Meskipun begitu kemampuan membaca anak sering mengalami kendala terutama dalam kemampuan berbahasa verbal serta mengenal huruf maupun kata. Tahapan perkembangan Bahasa anak terutama kemampuan membaca dan mengenal baik huruf vocal dan huruf konsonan (Pertiwi, 2017)

(Basyiroh, 2017) menjelaskan pengajaran membaca permulaan ditekankan kepada pengembangan kemampuan dasar membaca permulaan. Kemampuan membaca permulaan tersebut yaitu kemmpuan untuk menyuarakan huruf, suku kata, kata dan kalimat, yang disajikan dalam bentuk lisan. Anak mulai menggabungkan bunyi huruf menjadi suku kata dan kata yang memunculkan makna dari kata-kata tersebut. Kemampuan membaca permulaan anaka dalah keterampilan dasar anak pada aspek bahasanya yang dijadikan bekal untuk memasuki perkembangan selanjutnya. Dalam membaca permulaan anak dapat mengenal berbagai bunyi huruf dan kata akan menambah pembendaharaan kata, wawasan pada anak, pemahaman terhadap situasi dan kejadian disekitar, dan dalam lingkup perkembangan keaksaraan (Brodin \& Renblad, 2019).

(Rahadian, Rohanda, \& Anwar, 2014) menjelaskan Kemampuan literasi Bahasa anak terutama dalam kemampuan membaca permulaan terdapat beberapa factor yang mempengaruhinya diantaranya adalah: factor fisiologis, intelektual. Lingkungan, dan psikologis. Factor fisiologis mencakup kesehatan fisik, neurologis. Factor intelektual mencakup hubungan positif antara kecerdasan yang diindikasikan oleh nilai kecerdasan individu (IQ) dan peningkatan kemampuan membaca, factor linkungan mencakup pengalaman anak dan kondisi sosial ekonomi keluarga, dan factor terakhir adalah psikologis mencakup motivasi, minat baca, kematangan sosio-emosional, kematangan emosi dan penyesuaian diri.

Perkembangan membaca permulaan anak usia 5-6 memiliki ciri khas perkembangan Bahasa anak terutama dalam mengembangkan kemampuan membaca permulaan anak diantaranya adalah sudah dapat mengucapkan lebih dari 2600 kata, kalimat anak mencapai enam sampai delapan kata, memahami lebih dari 20000 kata, sudah dapat berkomunikasi dengan jelas, menjelaskan kata-kata sederhana, dapat menggunakan kata-kata penghubung, kata depan, dan kata sandang, lingkup kosakata yang diucapkan misalkan warna, bentuk, ukuran, rasa, bau, suhu, keindahan, dan kecepatan, mengenal banyak huruf, mampu berpartisipasi dalam satu percakapan, dan mampu melakukan ekspresi diri (Pebriana, 2017; Yuliani, 2019).

Untuk mengembangkan kemampuan berbahasa anak terutama kemampuan membaca permulaan anak usia dini dibutuhkan metode pembelajaran yang menyenangkan dan menarik bagi anak serta mendorong anak untuk semakin gemar membaca. Salah satu metode yang bisa digunakan untuk mengembangkan literasi Bahasa membaca permulaan adalah metode dia tampan. Metode pembelajaran dia tampan ini lebih menekankan tentang pengenalan huruf ((Jauhari, Marhaeni, \& Sutama, 2013). Proses penerapannya menggunakan langkah mulai dari huruf vocal dan konsonan yang diantaranya adalah huruf $d, n, t, p, m$, yang dirangkaikan dengan huruf vocal yang terdiri dari huruf a,I,u,e,o sehingga membentuk kata-kata bermakna kemudian menyebutkan kata yang sudah disusun tersebut (Jauhari et al., 2013). Keunggulan dari metode dia tampan adalah anak lebih cepat memahami isi materi dan media pembelajaran atau Alat Permainan Edukatif sehingga mampu memotivasi anak dalam belajar sehingga proses perkembangan literasi Bahasa anak usia 5-6 tahun terutama dalam kemampuan membaca permulaan di Pendidikan Anak Usia Dini (PAUD). 


\section{METODOLOGI}

Penelitian yang digunakan adalah penelitian kualitatif. Jenis Pendekatan dari penelitian kualitatif yang digunakan adalah dengan pendekatan deskriptif kualitatif dimana data yang didapatkan adalah berasal dari pelaksanaan kegiatan pembelajaran dengan menggunakan metode dia tampan untuk melihat sejauh mana pengembangan literasi anak usia 5-6 tahun terutama kemampuan membaca permulaannya. Subyek yang digunakan sebagai sampel adalah menggunakan anak usia 5-6 tahun di TK Hamzanwadi PAncor. Teknik pengumpulan data yang digunakan adalah dengan menggunakan menggunakan lembar observasi atau pengamatan tentang kemampuan membaca permulaan anak, wawancara untuk mengetahui perubahan yang terjadi terhadap perkembangan literasi Bahasa membaca permulaan pada anak usia 5-6 tahun, dan Dokumentasi. Instumen pengumpulan data yang digunakan adalah human instrumen, pedoman wawancara dan juga lembar observasi. teknik analisis data yang digunakan untuk mengelompokkan data berdasarkan variabel dan jenis responden, menyajikan data tiap variabel, melakukan perhitungan untuk memperoleh hasil dari pengggunaan metode dia tampan untuk mengembangkan literasi Bahasa membaca permulaan anak usia 5-6 tahun. Dalam penelitian kualitatif ada banyak analisis data yang dapat digunakan. Uji keabsahan data untuk penelitian ini didasarkan dengan empat kriteria yaitu derajat kepercayaan (uji credibility), Keteralihan (Uji Transferability), kebergantungan (dependability) dan kepastian (confirmability). Proses analisis data dilakukan dengan menggunakan model analisis interaktif Miles \& Huberman (1994:12) yang diantaranya adalah : (1) Pengoleksian Data dengan mengumpulkan data tentang penerapan metode dia tampan dalam pembelajaran terutama untuk mengembangkan literasi Bahasa anak usia 5-6 tahun terutama dalam membaca permulaan; (2) Display Data dari berbagai instrument yang digunakan mulai dari hasil wawancara, hasil observasi dan dokumentasi pelaksanaan kegiatan; (3) Reduksi Data dengan memilih hasil pengumpulan data yang dilakukan diantaranya adalah hasil data instrument, hasil penerapan metode dia tampan, dan juga proses kegiatan pembelajaran yang digunakan; dan (4) Penggambaran hasil (Conclusion Drawing) (Miles \& Hubberman. 2001).

\section{HASIL DAN PEMBAHASAN}

\section{Hasil Penelitian}

Kegiatan pembelajaran dengan menggunakan metode dia tampan bagi anak usia dini merupakan salah satu kegiatan pembelajaran yang menyenangkan terutama untuk mengembangkan kemampuan literasi Bahasa terutama membaca permulaan pada anak usia dini. Kesukaan anak dalam pembelajaran menghasilkan perkembangan anak yang sesuai dengan aspek perkembanagannya. Lingkup penilaian Pengembangan literasi Bahasa membaca permulaan anak usia 5-6 tahun melalui metode pembelajaran dia tampan membuat proses aspek perkembangan tercapai dengan baik.

Berdasarkan hasil pengumpulan yang dilakukan di TK Hamzanwadi tentang Pengembangan Literasi Bahasa Membaca Permulaan Anak usia 5-6 tahun didapatkan bahwa dalam proses kegiatan pembelajaran dengan menggunakan metode Dia Tampan anak diberikan perlakuan dalam proses pembelajarannya. Pada proses kegiatan pembelajaran menggunakan metode dia tampan, ada beberapa kegiatan yang diberikan di antaranya: Apersepsi, Membagi anak menjadi dua kelompok yaitu kelompok lingkaran dalam dan luar, Berputar mencari pasangan sambil mengenalkan huruf-huruf konsonan dasar seperti $d, b, s$, $r$, p; (4) berkomunikasi sesama teman dengan menyebutkan huruf konsonan dan huruf vocal a,I,u,e,o. Proses pembelajaran berjalan cukup menarik dan anak-anak sangat antusias ketika melakukan kegiatan dengan metode dia tampan tersebut. -anak aktif berkomunikasi dan juga menyebutkan isi dari penggabungan huruf vocal dan konsonan seperti Dadu, buku, gigi, dan lainnya. Selain itu, antusias anak juga dapat dilihat dari kemauan anak untuk menyebutkan kata yang dipajang di papan tulis. . 
Adapun hasil yang diperoleh dari penerapan metode dia tampan untuk mengembangkan kemampuan literasi Bahasa membaca permulaan anak dengan persentase rata-rata sebesar $45 \%$ atau sekitar 9 orang anak yang termasuk dalam kategori "Berkembang Sesuai Harapan".Sedangkan pada saat dan 35\% atau 7 orang anak yang kategori kemampuan literasi Bahasa membaca permulaan dengan kriteria "berkembang dengan Baik" dan sekitar 20\% atau 4 orang anak yang masuk kriteria " mulai Berkembang" Faktor pendukung yang mempengaruhi peningkatan ini, dikarenakan proses pembelajaran yang aktif dengan menggunakan strategi dia tampan yang membuat anak serta anak-anak menemukan hal yang baru dan lebih terlihat kesempatan berkomunikasi sesama temannya banyak tidak menekankan pada komunikasi satu arah. Untuk lebih jelasnya perkembangan literasi berbahasa membaca permulaan anak usia prasekolah atau anak usia 5-6 tahun dijabarkan dalam diagram berikut ini:

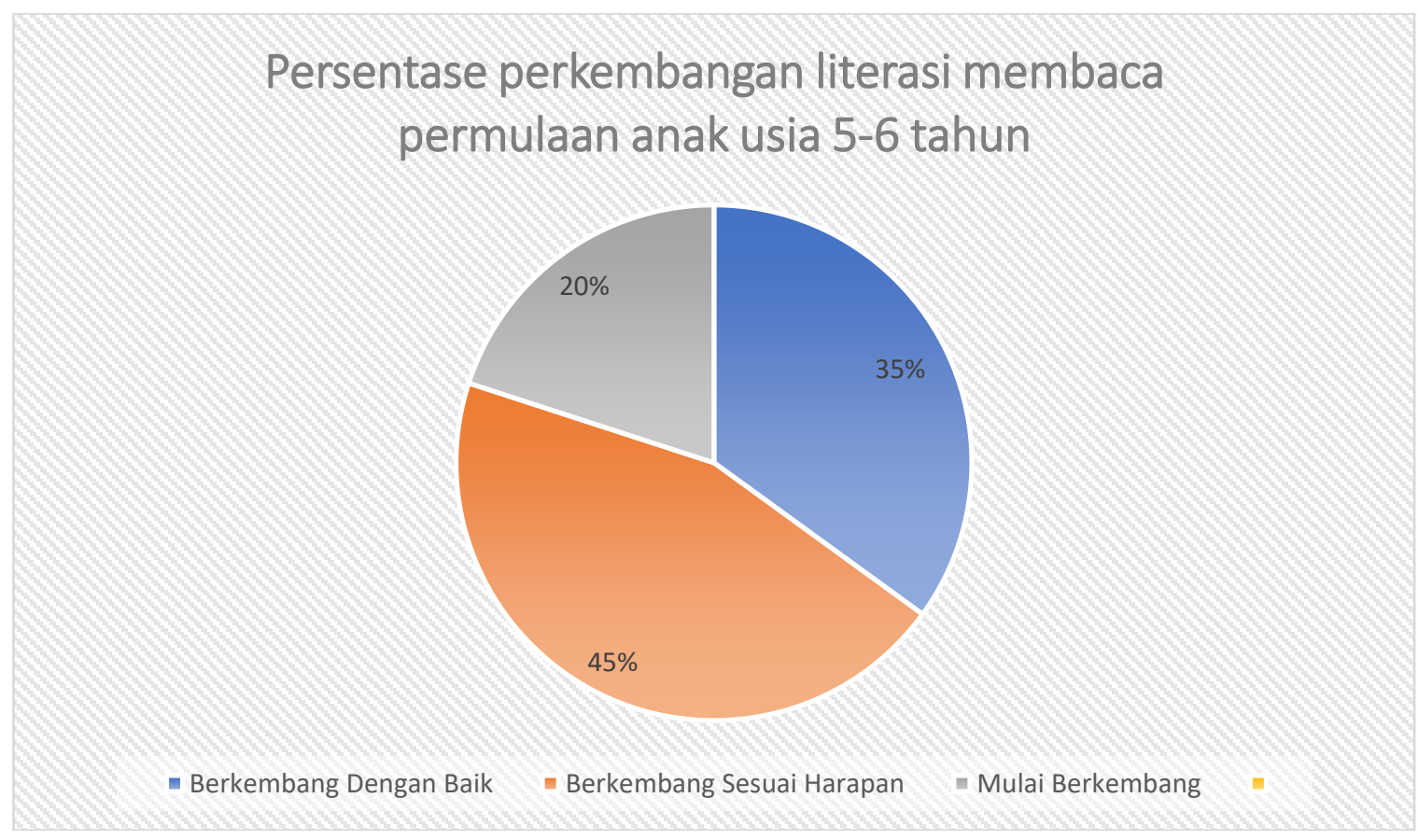

Gambar.1 Persentase perkembangan literasi memabaca permulaan anak usia 5-6 tahun

\section{PEMBAHASAN}

Kemampuan berbahasa anak dapat dioptimalkan menggunakann kegiatan dan pembelajaran yang sesuai dengan anak dan sesuai dengan aspek perkembangan yang dikembangkan. Salah satunya adalah metode dia tampan. salah satu keunggulan dari metode dia tampan yaitu adanya setruktur yang jelas dan memungkinkan anak untuk saling berbagi informasi dengan singkat dan teratur. Selain itu, siswa memiliki banyak kesempatan untuk mengolah informasi dan meningkatkan keterampilan berkomunikasi terutama dalam kemampuan membaca permulaannya

Kegiatan pembelajaran dengan menggunakan metode dia tampan ini dapat meningkatkan kemampuan berbahasa anak terutama dengan membaca permulaan. Anak mendapatkan pengalaman secara langsung karena anak mendapatkan kesempatan untuk mempraktekkan setiap kegiatan yang dilakukan dalam proses pembelajaran. Berdasarkan hasil pelaksanaan tersebut didapatkan Dari hasil diatas menunjukkan bahwa kemampuan membaca permulaan pada anak 5-6 tahun dalam tahap suku kata terbuka memasuki kategori Berkembang Sesuai Harapan (BSH). Hasilnya menunjukkan bahwa Kemampuan anak dalam menggabungkan 1 huruf konsonan dan 1 huruf vokal tergantung pengetahuan anak terhadap bunyi huruf vokal maupun konsonan. Anak yang memiliki pengetahuan huruf belum cukup banyak dari berbagai jenis huruf konsonan maka akan cenderung 
memilih huruf konsonan yang diketahui atau disukai oleh anak, sedangkan anak yang mempunyai pengetahuan minim tentang huruf vokal dan konsonan akan kesulitan ketika menggabungkan atau mengucapkan bunyi huruf untuk digabungkan.

Jika pengetahuan anak tentang huruf vokal dan konsonan tinggi atau pengetahuan tentang huruf vokal dan konsonan banyak maka akan memudahkan anak dalam membaca atau mengeja suku kata yang terdiri dari satu huruf vokal dan satu huruf konsonan berdasarkan pengetahuan huruf yang sudah dimiliki oleh anak. Kemampuan anak dalam mengucapkan bunyi huruf vokal-konsonan-vokal terlihat lebih sukar diucapkan karena mengandung 3 huruf. Kemampuan anak mengucapkan bunyi huruf KVKV yang berbeda terlihat lebih sukar Anak lebih sukar membaca karena anak harus mengeja semua huruf tersebut dahulu, jika anak mampu dengan mudah mengeja huruf maka anak akan mengucapkan secara cepat Penerapan metode dia tampan dalam mengembangkan kemampuan literasi Bahasa anak terutama membaca permulaan memberikan terobosan baru dalam proses pembelajaran, dimana anak diberikan kesempatan untuk menjelaskan materi ajar dengan menyebutkan huruf vocal dan huruf konsonan terlebih dahulu.

Keterampilan membaca anak dapat meningkat karena mereka dipengaruhi oleh beberapa faktor, sebagaimana dinyatakan oleh (Iasha \& Iswara, 2018) mengenai faktor-faktor yang mempengaruhi minat membaca anak termasuk 1) motivasi, 2) lingkungan keluarga, 3) bahan bacaan. Motivasi kegiatan membaca terutama memabaca permulaan untuk anak usia 5-6 tahun memberi pengaruh besar pada keterampilan membaca anak. Anak yang memiliki keinginan untuk membaca keterampilan membaca mereka adalah baik. Hal ini dapat dilihat dari perhatian anak ketika belajar membaca dini, anak yang memiliki motivasi membaca yang tinggi akan memperhatikan guru ketika memberikan contoh bacaan yang benar sehingga siswa akan dapat memiliki keterampilan membaca yang baik. Faktor-faktor lain yang mempengaruhi kemampuan membaca permulaan anak usia 5-6 6 tahun (Anggraeni, Hartati, \& Nurani, 2019; Ramdhani, Yuliastri, Sari, \& Hasriah, 2019) terkait dengan bahan bacaan, bahan serta kegiatan membaca yang digunakan dalam meningkatkan literasi berbahasa membaca permulaan anak usia 5-6 tahun juga sangat berpengaruh terhadap keterampilan membaca yang dipelajari serta metode yang digunakan dalam membaca. Bahan bacaan mempengaruhi pembaca untuk memiliki minat dalam membaca dan kemampuan untuk memahami isi bacaan.

Metode pembelajaran dia tampan dapat pula dilakukan dengan menggunakan bantuan kata bergambar sehingga lebih menekankan pada pengenalan kemampuan literasi dini AUD. Tujuan dari penerapan metode pembelajaran dia tampan adalah untuk menjembatani anak sejak dini diperkenalkan kemampuan literasi berbahasa membaca permulaannya. (Iasha \& Iswara, 2018). (Jauhari et al., 2013; Yuliani, 2019) Kemampuan literasi merupakan salah satu aspek perkembangan anak usia dini. Kemampuan literasi merupakan kemampuan yang dibawa anak sejak lahir dan sangat bermanfaat bagi kehidupan anak selanjutnya. anak memiliki pengalaman literasi berbahasa sebelum mengetahui tentang keaksaraan sangat penting bagi perkembangan mereka. anak sejak lahir sudah mulai belajar literasi dini melalui membaca cerita oleh orang tuanya, bercakap-cakap walaupun dalam kandungan ia tidak memberikan respon. (Basyiroh, 2017; Cahyani, 2016) Pada kenyataanya semua anak ingin menyerap informasi apa saja yang ada disekitar lingkungan sekitar melalui aktivitas membaca dan menulis dengan penekanan peningkatan kemampuan anak. Dengan demikian menulis dan membaca merupakan sebagai kebutuhan yang harus dimiliki anak,

Melalui pembelajaran yang menyenangkan, dengan sendirinya anak dapat menerima dan menyerap informasi yang disampaikan dalam proses pembelajaran. Pembelajaran yang sesuai dengan kebutuhan anak membuat anak tidak merasa terbenani dan merasa sedang tidak membelajarkan sesuatu. (Brodin \& Renblad, 2019) menjelaskan salah satu letak kesuksesan anak belajar adalah dengan memposisikan anak dalam situasi dan lingkungan yang kondusif serta ketersediaan model, media serta metode yang sesuai dengan kebutuhan 
anak. Dengan demikian anak secara cepat menyerap informasi sehingga kegiatan literasi berbahasa membaca permulaan menjadi sesuatu yang meyenangkan bagi anak. Perkembangan literasi dini yang paling pesat dan cepat adalah ketika anak sedang berada pada periode emas (golden age) yaitu usia 0-6 tahun (Chairilsyah, 2019). Pada usia dini anak lebih cepat dan mudah berkembang berkaitan dengan kemampuan literasinya (Kostelnik, Soderman, whiren, 2007). kesempatan anak untuk belajar bahasa adalah ketika masih usia dini. Bahasa yang digunakan anak tidak sebatas pada bahasa lisan namun juga menggunakan bahasa isyarat dan bahasa tulisan. Anak-anak mempelajari kemampuan literasi berbahasa membaca permulaan dengan cara yang sangat menakjubkan. Adapuan cara untuk memfasilitasi anak mengembangakan kemampuan literasi adalah menggunakan bahasa secara oral, menyediakan buku, pendekatan untuk membaca buku, hasil menulis anak, kurikulum yang terpadu, pemahaman akan keberagaman, memfasilitasi dukungan keluarga untuk mengenalkan huruf kepada anak.

\section{KESIMPULAN}

Kegiatan pembelajaran dengan menggunakan metode dia tampan bagi anak usia dini merupakan salah satu kegiatan pembelajaran yang menyenangkan terutama untuk mengembangkan kemampuan literasi berbahasa terutama membaca permulaan pada anak usia dini. hasil yang diperoleh dari penerapan metode dia tampan untuk mengembangkan kemampuan literasi Bahasa membaca permulaan anak dengan persentase rata-rata sebesar $45 \%$ atau sekitar 9 orang dengan kategori "Berkembang Sesuai Harapan". Sedangkan pada saat dan 35\% atau 7 orang anak dengan kriteria "berkembang dengan Baik" dan sekitar 20\% atau 4 orang anak dengan kriteria " mulai Berkembang". Faktor pendukung yang mempengaruhi peningkatan ini, dikarenakan proses pembelajaran yang aktif dengan menggunakan strategi dia tampan yang membuat anak serta anak-anak menemukan hal yang baru dan lebih terlihat kesempatan berkomunikasi sesama temannya banyak tidak menekankan pada komunikasi satu arah. Metode pembelajaran dia tampan dapat pula dilakukan dengan menggunakan bantuan kata bergambar media pembelajaran inovatif, Alat Permainan Edukatif dan Lainnya.

\section{UCAPAN TERIMAKASIH}

Ucapan terima kasih kepada Universitas Hamzanwadi yang telah memberikan fasilitas dalam proses penelitian sehingga dapat tersusun artikel ini. Keluarga Besar TK Hamzanwadi sebagai tempat dalam melaksanakan penelitian sehingga memperoleh data yang dibutuhkan, tim pengumpul data, dan tim penterjemah abstrak.

\section{DAFTAR PUSTAKA}

Anggraeni, D., Hartati, S., \& Nurani, Y. (2019). Jurnal Obsesi : Jurnal Pendidikan Anak Usia Dini Implementasi Metode Bercerita dan Harga Diri dalam Meningkatkan Kemampuan Berbicara Anak Usia Dini, 3(2), 404-415. https:/ / doi.org/10.31004/obsesi.v3i2.224

Astuti, S. K. (2016). Pelaksanaan Pembelajaran Membaca Permulaan DI Kelompok A Taman Kanak-kanak Aba Pendowo. Jurnal Pendidikan Guru Pendidikan Anak Usia Dini, (3), 194204.

Awal, M., \& Mutiara, T. K. (2019). Efektivitas Permainan Pola Suku Kata Terhadap Kemampuan Membaca Awal Anak di Taman Kanak-Kanak Mutiara Ananda Tabing Padang, (2). https://doi.org/10.31004/obsesi.v2i1.13.

Basyiroh, I. (2017). Program Pengembangan Kemampuan Literasi Anak Usia Dini. Tunas Siliwangi, 3(2), 120-134.

Brodin, J., \& Renblad, K. (2019). Improvement of preschool children's speech and language skills. Early Child Development and Care, 0(0), 1-9. https:// doi.org/10.1080/03004430.2018.1564917 
Cahyani, N. I. (2016). Kemampuan Anak Berbahasa Ditinjau, 1-11.

Chairilsyah, D. (2019). Web-Based Application to Measure Motoric Development of Early Childhood. JPUD - Jurnal Pendidikan Usia Dini, 13(1), 1-14. https:// doi.org/10.21009/10.21009/jpud.131.01

Habibi, M., Fip Unp, P., \& Padang, K. (2018). Keterampilan Membaca Dan Menulis Permulaan Menggunakan Model Vark Untuk Siswa Sekolah Dasar. Jurnal Inovasi Pendidikan Dan Pembelajaran Sekolah Dasar, 2(1), 72-80. Retrieved from http://ejournal.unp.ac.id/index.php/jippsd72. https://doi.org/10.24036/jippsd.v2i1.100032.

Iasha, Y. D., \& Iswara, P. D. (2018). Big Book Media Development Of Real Reading Ability and Communication Ability of Students Using Dia Tampan Strategy ( Experimental Research at Class I SDIT Cendekia Purwakarta Purwakarta District, Purwakarta Regency ), 233-243.

Inten, D. N. (2017). Peran Keluarga dalam Menanamkan Literasi Dini pada Anak Role of the FamilyToward Early Literacy of the Children. Golden Age: Jurnal Pendidikan Anak Usia Dini, 1(1), 23-32. https://doi.org/10.29313/ga.v1i1.2689

Jauhari, S., Marhaeni, A. A. I. ., \& Sutama, M. (2013). Pengaruh Implementasi Strategi Dia Tampan Berbantuan Media Audio Visual Terhadap Hasil Belajar Membaca Permulaan. Jurnal Pendidikan Dasar Ganesha, 3(1). Retrieved from https://www.neliti.com/id/publications/120912/ pengaruh-implementasi-strategi-diatampan-berbantuan-media-audio-visual-terhadap

Huberman, M., \& Miles, M. B. (2002). The qualitative researcher's companion. Sage. https:// doi.org/10.4135/9781412986274.

Nur Azizah, A., \& Ali, M. (n.d.). Penanaman Nilai Moral Melalui Metode Bercerita Pada Anak Usia 5 - 6 Tahun Di Tk Khodijah, 1-16.

Nuraeni, A. (2016). Peran Orang Tua dalam Pengembangan Literasi Dini Anak Kelompok B di Gugus 7 Mangunan Dlingo Bantul. Jurnal Pendidikan Anak Usia Dini, 3, 245-256. Retrieved from http://journal.student.uny.ac.id/ojs/index.php/pgpaud/article/viewFile/1256/1131

Olufunke, M. (2013). Literacy in Early Childhood: Implications for Sustainable Development, 24-26.

Palupi, Y., \& Pendahuluan, I. (2015). Perkembangan Bahasa Pada Anak. Wardah, 14(1), 25-33.

Pebriana, P. H. (2017). Jurnal Obsesi: Jurnal Pendidikan Anak Usia Dini Analisis Penggunaan Gadget terhadap Kemampuan Interaksi Sosial. Jurnal Pendidikan Anak Usia Dini, 1(1), 8. https:// doi.org/10.31004/obsesi.v1i1.26

Pertiwi, A. D., Universitas, P., \& Yogyakarta, N. (2017). Study Deskriptif Proses Membaca Permulaan Anak Usia Dini. Jurnal Pendidikan Anak, 5(1), 759-764.

Rahadian, G., Rohanda, R., \& Anwar, R. K. (2014). Peranan Perpustakaan Sekolah Dalam Meningkatkan Budaya Gemar Membaca. Jurnal Kajian Informasi Dan Perpustakaan, 2(1), 47. https://doi.org/10.24198/jkip.v2i1.11628

Ramdhani, S., Yuliastri, N. A., Sari, S. D., \& Hasriah, S. (2019). Penanaman Nilai-Nilai Karakter melalui Kegiatan Storytelling dengan Menggunakan Cerita Rakyat Sasak pada Anak Usia Dini. Jurnal Obsesi: Jurnal Pendidikan Anak Usia Dini, 3(1), 153. https:// doi.org/10.31004/obsesi.v3i1.108

Sumaryanti, L. (2018). Membudayakan Literasi Pada Anak Usia Dini Dengan Metode Mendongeng. AL-ASASIYYA: Journal Of Basic Education, 3(1), 117. https:// doi.org/10.24269/ajbe.v3i1.1332

Suyadi, S. (2017). Perencanaan dan Asesmen Perkembangan Pada Anak Usia Dini. Golden Age: Jurnal Ilmiah Tumbuh Kembang Anak Usia Dini, 1(1), 65-74. Retrieved from http:/ / ejournal.uin-suka.ac.id/tarbiyah/index.php/goldenage/article/view/1251

Yuliani, N. (2019). Perspektif Baru Konsep Dasar Pendidikan Anak Usia Dini, 141.

Yuliani Nurani, S. (2012). Konsep Dasar Pendidikan Anak Usia Dini. Cetakan Kelima., 1-40. 